\title{
A Research on the Breeding Activities of Organic Beekeeping Enterprises
}

\section{Tunay Kılıçin ${ }^{1, *} \mathbb{D}$, Gökhan Akdeniz $^{1} \mathbb{D}$, Salim Aktürk $^{1}{ }^{\mathbb{D}}$, Dilek Kabakcı ${ }^{\mathbb{D}}$, Ümit Karataş ${ }^{1}\left(\mathbb{D}\right.$, Soner Çankaya ${ }^{3}$}

\author{
${ }^{1}$ Apiculture Research Institute Directorate, Ordu, Turkey \\ ${ }^{2}$ Muş Alparslan University, Department of Animal Production and Technologies, Faculty of Applied Sciences, Muş, \\ Turkey \\ ${ }^{3}$ Ondokuz Mayıs University, Yaşar Doğu Sport Science Faculty, Samsun, Turkey
}

\section{Article History}

Received 25 June 2021

Accepted 28 July 2021

First Online 28 July 2021

\section{*Corresponding Author \\ Tel.: +905434222058 \\ E-mail: \\ tunay.kilicin@tarimorman.gov.tr}

\author{
Keywords \\ Honey \\ Organic beekeeping \\ Pollen \\ Production \\ Transition period
}

\begin{abstract}
With its low investment cost, beekeeping is an important agricultural activity that can be done without being connected to the soil and allows beekeepers to increase their income levels in a short time. On the other hand, organic beekeeping is a production model made only with allowed inputs without using drugs that are harmful to human health and whose every stage is controlled and certified from production to consumption. This study, it was aimed to examine the structure and production activities of organic beekeeping enterprises. The primary material of the study was data collected from 118 organic beekeeping enterprises. It was determined that $50.70 \%$ of the enterprises obtained the queen bee by natural methods, $23.4 \%$ by larva transfer, $26.6 \%$ from commercial queen bee enterprises, and $64.52 \%$ used pure Caucasian or Caucasian hybrid bee races in their colonies. The annual colony loss of the enterprises was $19.44 \%$, and it was observed that colony loss was $50 \%$ higher in enterprises that obtained the queen bee commercially and bred it by natural means compared to enterprises that transferred larvae. It was determined that enterprises that considered organic beekeeping as the first profession had a higher number of colonies $(P=0.007)$ and $25 \%$ fewer colony losses $(P=0.088)$ than enterprises that saw it in the second and third orders. Finally, it was found that $53.69 \%$ of enterprises made additional feeding only with honey they produced, and the production of other organic bee products other than honey in enterprises was very limited.
\end{abstract}

\section{Introduction}

Organic beekeeping is a production model made only with allowed inputs without using drugs that are harmful to human health and whose every stage is controlled and certified from production to consumption (Korkmaz, 2001). Organic beekeeping can only be done in organic farming areas or pastures and plateaus where the natural structure is intact. Within a radius of $5-7 \mathrm{~km}$, that is a bee flight distance or at least in a $3 \mathrm{~km}$ area that bees use very intensively, industrial facilities and their waste and treatment centers, highways, and waste incineration plants should not be present (Emsen \& Genç, 2004). It is possible to perform organic honey and pollen production, especially in vast pasture areas, pine forests, and areas containing nectarblooming plants, such as acacia, chestnut, and linden (Gökçe, 2002). One of the mandatory requirements of the transition from conventional beekeeping to organic beekeeping is to control the infrastructure residues released and honeycombs in the colony and meet the needs of beekeepers transitioning to organic beekeeping, such as organic beeswax (Gül, Şahinler, Akyol, \& Şahin, 2005). 
Table 1 shows that 70385 colonies, 387 organic beekeepers produced 1028 tons of organic honey in Turkey, according to the 2020 statistics of the General Directorate of Plant Production of the Ministry of Agriculture and Forestry (Anonymous, 2021).

In recent years, one of the most important actors of organic agriculture aimed at restoring the natural balance that has deteriorated and disappeared in the ecosystem is honey bees which are away from all kinds of inputs and elements that can be harmful to human health and whose every stage from production to consumption is controlled and certified. In addition, honey bees play a vital role in the ability of most plants to continue their generation and in the enrichment of the natural plant vegetation. The honeybee is considered an indispensable element of agriculture and used effectively in pollination is mandatory in Turkey. Thus, on the one hand, natural pasture areas with appropriate ecology and genetic richness are evaluated for beekeeping, while on the other hand, the quality and quantity in plant production are being increased (Cengiz, 2013). It is observed that producers who had started organic beekeeping returned to conventional beekeeping, especially during the transition process. Therefore, to meet certain conditions and overcome difficulties in the transition to organic beekeeping, scientific research is needed (Saner et al., 2011). This study, it was aimed to examine the structure and production activities of organic beekeeping enterprises.

Table 1. Data on organic beekeeping between 2010 and 2020

\begin{tabular}{cccccc}
\hline & \multicolumn{3}{c}{ Organic Beekeeping Data } & \multicolumn{2}{c}{ Transition Period } \\
\hline Year & $\begin{array}{c}\text { Number of } \\
\text { Producers }\end{array}$ & $\begin{array}{c}\text { Colony } \\
\text { Presence }\end{array}$ & $\begin{array}{c}\text { Production } \\
\text { (tons) }\end{array}$ & $\begin{array}{c}\text { Number of } \\
\text { Producers }\end{array}$ & Colony Presence \\
\hline 2020 & 387 & 70385 & 1028.39 & 107 & 18743 \\
2019 & 249 & 50100 & 576.76 & 170 & 21484 \\
2018 & 334 & 51742 & 493.89 & 121 & 17313 \\
2017 & 304 & 45848 & 391.10 & 273 & 41014 \\
2016 & 276 & 40731 & 349.00 & 364 & 35871 \\
2015 & 322 & 38296 & 421.49 & 238 & 32680 \\
2014 & 321 & 36391 & 280.00 & 213 & 22634 \\
2013 & 279 & 32342 & 344.00 & 471 & 62836 \\
2012 & 355 & 47065 & 516.83 & 395 & 45077 \\
2011 & 205 & 19105 & 221.31 & 549 & 53554 \\
2010 & 191 & 14699 & 208.15 & 225 & 13258 \\
\hline
\end{tabular}

\section{Materials and Methods}

The main material of the study was data collected from the organic beekeeping enterprises, which were determined by the simple random sampling method, through conducting face-to-face interviews with the help of a survey. The population of the research was 696 organic beekeeping enterprises operating in Turkey. During the sampling process, the presence of colonies owned by organic beekeeping enterprises was used as a sampling criterion, and it was studied on a $10 \%$ margin of error and $95 \%$ confidence interval. The number of beekeepers to be surveyed was determined by using the following formula calculated by taking the number of hives as criteria and using the "simple random sampling" method (Yamane, 1967).

$$
n=\frac{N(z C)^{2}}{N d^{2}+(z C)^{2}}
$$

Where $N$ is the number of beekeepers in the population, $z$ is the standard normal distribution value corresponding to the desired degree of confidence (1.95), $C$ is the coefficient of variation, $d$ is the margin of error accepted in the study ( $\pm 10 \%)$, and $n$ is the number of beekeepers to be surveyed. Accordingly, the number of beekeepers to be surveyed was 192 with a 95\% confidence degree and a $10 \%$ margin of error. It was found that $61.46 \%$ of enterprises (118) were engaged in organic production activities, $13.02 \%$ (25 enterprises) were in the transition period, $16.67 \%$ (32 enterprises) had left the transition period, and $8.85 \% \quad$ (17 enterprises) had given up organic production. In this study, we used the surveyed data collecting from 118 actively carried out organic beekeeping enterprises.

In the evaluations of the data obtained from the enterprises participating in the survey study, some descriptive statistics such as arithmetic and weighted mean, $n$, and percentage (\%) were used. Primarily, normality and variance homogeneity tests were applied to the continuous data of the study $(P>0.05)$. Differences among colony numbers or loss of the enterprises by professional priority order variables were determined by one-way ANOVA and the Tukey's Multiple Comparison test. On the other hand, the Pearson correlation coefficient revealed the relationship between the properties studied in the study. In addition, the structure of the relationship between variables 
showing categorical properties was evaluated by chisquare $(\chi 2)$ analysis (Fisher's exact test).

\section{Findings and Discussion}

The survey was conducted with 118 beekeepers and $97.46 \%$ of the interviewees were male and $2.54 \%$ were female. The mean age of beekeepers was 51.60, and while the oldest beekeeper was 74 years old, the youngest beekeeper was 28 years old. In terms of the educational level of the beekeepers, $1.69 \%$ were literate, $29.66 \%$ were primary school, $16.95 \%$ were secondary school, $27.12 \%$ were high school, $11.02 \%$ were college, and $13.56 \%$ were undergraduate graduates.

It was found that $61.46 \%$ of enterprises (118) were engaged in organic production activities, 13.02\% (25 enterprises) were in the transition period, $16.67 \%$ (32 enterprises) had left the transition period, and $8.85 \%$ (17 enterprises) had given up organic production. $42.37 \%$ of the enterprises carrying out organic production were engaged in migratory beekeeping, and $57.63 \%$ were engaged in stationary beekeeping. It was revealed that enterprises had an average of 27 years of experience in beekeeping activities, and 1.65 years of this experience had been gained in the transition period and 5.64 years in organic beekeeping cultivation. In a study conducted in Gökçeada district of Çanakkale province, when agricultural activity, beekeeping, and organic beekeeping experiences of organic beekeeping enterprises were examined, it was determined that agricultural activity experiences were 16.1 years, beekeeping experiences were 8.9 years, and organic beekeeping experiences were 6.4 years on average (Özsayın, Tan, \& Everest, 2018). In another study conducted in Kemalpaşa district of Izmir province, it was found that the experiences of beekeepers were 26 years in agricultural activities and were 14.6 years in organic beekeeping activities (Saner et al., 2011).

In this study, $75.21 \%$ of the enterprises said they kept records, while $24.79 \%$ said they did not keep any records. $19.47 \%$ of these enterprises stated that they kept records related to queen bee exchange, $19.47 \%$ related to diseases and pests, $19.47 \%$ related to input amounts and application times of breeding, $6.84 \%$ related to information belonging to organic companies or other organizations, $7.37 \%$ related to prices, expenditures and costs, and $6.84 \%$ related to all stages of production. In the study, it was found that the recordkeeping status in organic beekeeping enterprises did not change depending on the training status of beekeepers $\left(\chi^{2}=4.852 ; P=0.434\right)$.

$59.83 \%$ of organic beekeepers found the services of the certification bodies adequate. The average number of visits of certification bodies to the organic beekeeping enterprises was determined as 2.21 days/year.

Factors that were effective on enterprises to decide to start organic beekeeping activities are given in Table 2. It was determined that in making this decision, their own experience had been effective at a rate of $27 \%$, the officials of the Ministry of Agriculture and Forestry at a rate of $24 \%$, and the foundations and chambers at a rate of $17 \%$.

Table 2. Effective factors on the decision of the enterprises to start organic beekeeping activities

\begin{tabular}{lcc}
\hline Preferences & Number of & Frequency (\%) \\
\hline My Own Experience & 32 & 27 \\
Officials of the Ministry of Agriculture and Forestry & 28 & 24 \\
Foundations and chambers & 20 & 17 \\
Neighbor Friend & 19 & 16 \\
Union Officials & 10 & 8 \\
Certification Firm Officials & 7 & 6 \\
Agricultural Consultants & 2 & 2 \\
\hline Total & 118 & 100 \\
\hline
\end{tabular}

Sources of knowledge obtained by enterprises engaged in organic beekeeping related to the methods used in organic production are given in Table 3. In Table 3 , it is seen that $18.47 \%$ of the enterprises obtained knowledge from the certification bodies which they worked together, $16.67 \%$ from the training, seminars and course programs they attended, $13.06 \%$ from books and brochures, $12.16 \%$ from leading beekeepers, $12.16 \%$ from the technical personnel of the Ministry, 9.91\% via the internet, $7.66 \%$ from agricultural consultants, $5.41 \%$ from Union staff, and $4.50 \%$ from foundation and chamber representatives. A study conducted in Gökçeada District of Çanakkale province showed Provincial-District directorates of agriculture as the most important source of knowledge for organic beekeeping enterprises (Özsayın et al., 2018). In a study conducted in Kemalpaşa District of Izmir province, on the other hand, it was determined that most of the beekeepers received knowledge from the Beekeepers Association, universities, and district directorates of agriculture (Saner et al., 2011).

The production quantities of bee products and their rates are given in Table 4 below. It was found that the most produced bee products in the enterprises after honey are pollen, wax, propolis (bee glue), and royal jelly, respectively. In enterprises, other organic bee products other than honey were observed to be carried out at extremely limited levels.

Regarding of collected data of the field study, 118 enterprises produce $1395.86 \mathrm{~kg}$ honey and 21 
enterprises have $185.48 \mathrm{~kg}$ pollen production. Moreover, other 16 enterprises have $17.40 \mathrm{~kg}$ propolis (Bee glue) production and 8 enterprises have been producing royal jelly an amount of $2.7 \mathrm{~kg}$. Furthermore, 6 organic honey bee enterprises have $126 \mathrm{~kg}$ of wax production.

In the study, it was determined that $50.70 \%$ of enterprises obtained the queen bee by natural methods, $23.4 \%$ by larva transfer, and $26.6 \%$ from commercial queen bee enterprises. $13.68 \%$ of organic production enterprises stated that they changed the queen bee every year, $65.81 \%$ every two years, $17.95 \%$ every three years, and $0.85 \%$ every four years. $1.71 \%$ of enterprises, on the other hand, said that the colony had changed its queen. Races and genotypes of queen bees used by the organic beekeeping enterprises in their colonies are given in Table $5.64 .52 \%$ of the enterprises were determined to use a pure Caucasian or Caucasian hybrid queen bee race in their colonies.

$8.39 \%$ of the enterprises reported using one of the Yigilca, Aegean, Mugla, Carpathian, Italian and Syrian queen bee races (Table 5). Additional feeding practices of the organic beekeeping enterprises are given in Table 6. $53.69 \%$ of the beekeepers stated that they made additional feeding only with honey they produced. It is observed that organic beekeeping enterprises use syrup and cake (41\%) intensively in feeding activities.

Table 3. Professional knowledge sources of organic beekeeping enterprises

\begin{tabular}{lcc}
\hline Knowledge Sources & Number of Enterprises $(\mathrm{n})^{*}$ & Frequency (\%) \\
\hline Certification Bodies & 41 & 18.47 \\
Training, seminars and courses & 37 & 16.67 \\
Books and brochures & 29 & 13.06 \\
Leading Beekeepers & 27 & 12.16 \\
Technical Personnel of the Ministry & 27 & 12.16 \\
Internet & 22 & 9.91 \\
Agricultural Consultants & 17 & 7.66 \\
Union Personnel & 12 & 5.41 \\
Foundation and Chambers & 10 & 4.50 \\
\hline Total & 222 & 100.00 \\
\hline
\end{tabular}

* Multiple responses were given by the enterprises

Table 4. The producers of organic bee products and their rates

\begin{tabular}{lcc}
\hline Organic Bee Products & Number of Enterprises ( $\mathrm{n})$ & Frequency (\%) \\
\hline Honey & 92 & 77.97 \\
Honey+Pollen & 7 & 5.93 \\
Honey+Propolis & 3 & 2.54 \\
Honey+Bee wax & 1 & 0.85 \\
Honey+Pollen+Propolis & 5 & 4.24 \\
Honey+Propolis+Royal jelly & 1 & 0.85 \\
Honey+Pollen+Bee wax & 1 & 0.85 \\
Honey+Pollen+Bee wax+Propolis & 1 & 0.85 \\
Honey+Pollen+Royal jelly+Bee wax & 1 & 0.85 \\
Honey+Pollen+Royal jelly+Propolis & 4 & 3.39 \\
Honey+Pollen+Royal jelly+Propolis+Bee wax & 2 & 1.69 \\
\hline Total & 118 & 100.00 \\
\hline
\end{tabular}

Table 5. Races and genotypes of queen bees used in the organic beekeeping enterprises

\begin{tabular}{lcc}
\hline Race and Genotypes & Number of Enterprises $(\mathrm{n})^{*}$ & Frequency (\%) \\
\hline Caucasian Hybrid & 77 & 49.68 \\
Pure Caucasian & 23 & 14.84 \\
Carniolan & 17 & 10.97 \\
Anatolian Bee & 14 & 9.03 \\
Other & 13 & 8.39 \\
Gokceada Bee & 7 & 4.52 \\
Buckfast Bee & 4 & 2.58 \\
\hline Total & 155 & 100.00 \\
\hline
\end{tabular}

* Multiple responses were given by businesses. 
Table 6. Additional feeding materials used in the organic beekeeping enterprises

\begin{tabular}{lcc}
\hline Additional Feeding Type & Number of Enterprises $(\mathrm{n})^{*}$ & Frequency $(\%)$ \\
\hline Honey & 80 & 53.69 \\
Cake + Syrup & 36 & 24.16 \\
Syrup & 14 & 9.40 \\
Cake & 11 & 7.38 \\
Not & 8 & 5.37 \\
\hline Total & 149 & 100.00 \\
\hline
\end{tabular}

* Multiple responses were given by businesses.

To the question "What are the diseases and pests seen in your colony", most of the enterprises answered of "varroa parasite". The fight times of the enterprises with the varroa parasite, which leads to severe colony losses worldwide, are given in Table 7. When Table 7 is examined, it is seen that almost all of the enterprises are fighting against the parasite at the right time. In addition, colony loss in the studied organic beekeeping enterprises was determined as $19.44 \%$.

Among the beekeepers participating in the study, the number of colonies of those who saw organic beekeeping as the first profession was found to be relatively high compared to those who saw it in the second, and third orders $(P=0.007)$ (Table 8). It was determined that colony numbers of enterprises that consider organic beekeeping as the first profession were higher $(P=0.007)$, and their colony losses were $25 \%$ less $(P=0.088)$ compared to enterprises that see it in the second and third orders (Table 9). In terms of honey production, no significant difference was determined by the professional priorities $(P=0.789)$.

$33 \%$ of the enterprises that saw beekeeping as the first of the professional priority order started to look for alternatives in terms of product diversity. $18 \%$ of the enterprises increased their product diversity, while about $15 \%$ reduced their product diversity $(P=0.05)$.

Table 7. Time for the organic beekeeping enterprises to against varroa

\begin{tabular}{lcc}
\hline Fight Time & Number of Enterprises $(\mathrm{n})$ & Frequency $(\%)$ \\
\hline Early Spring - Late Autumn & 65 & 55.08 \\
Spring-Autumn & 50 & 42.37 \\
Not against varroa & 2 & 1.69 \\
When varroa mite is appear & 1 & 0.85 \\
\hline Total & 118 & 100.00 \\
\hline
\end{tabular}

Table 8. Colony numbers of the enterprises by professional priority order

\begin{tabular}{lccccc}
\hline & $\mathrm{n}$ & Min & Max & Mean & Standard Deviation \\
\hline First priority & 77 & 9 & 500 & 136.13 & 117.113 \\
Second priority & 33 & 10 & 300 & 77.7 & 74.221 \\
Third priority & 6 & 30 & 70 & 43.67 & 17.224 \\
No response & 2 & - & - & - & - \\
\hline
\end{tabular}

$(P=0.007)$

Table 9. Colony loss of the enterprises by professional priority order

\begin{tabular}{lccccc}
\hline & $\mathrm{n}$ & Min(\%) & Max(\%) & Mean(\%) & Standard Deviation \\
\hline First priority & 72 & 2 & 80 & 16.90 & 15.097 \\
Second priority & 31 & 1 & 90 & 25.06 & 21.787 \\
Third priority & 5 & 10 & 30 & 21.00 & 8.944 \\
No response & 10 & - & - & - & - \\
\hline
\end{tabular}

$(P=0.088)$ 
It was observed that enterprises that increased product diversity were stationary beekeepers generally (Table 10).

It was found that in organic beekeeping enterprises, while the number of colonies of enterprises using both larval transfer and commercial queen bee as queen bee obtaining method was maximum (289 colonies/enterprises), the numbers of colonies of enterprises obtaining queen bee only natural ways ( 81 colonies/enterprises) and only commercial way (87 colonies/enterprises) were minimum $(P<0.001)$ (Table 11).

It was found that organic beekeeping enterprises that produce the queen bee by larval transfer had a higher number of colonies than those that did not. It was determined that although there were no statistically significant differences, the production of honey per colony in enterprises using only commercial queen bees (average $8 \mathrm{~kg}$ ) was 50\% less compared to enterprises producing queen bees by larval transfer (average $12 \mathrm{~kg}$ ). Similarly, it was observed that colony loss was $50 \%$ higher in enterprises that obtained the queen bee via commercial ways and bred the queen bee by natural means compared to enterprises that performed the larval transfer. It can be seen in Table 12, honey production increases as the number of colonies increases in the studied organic beekeeping enterprises ( $r=0.255 ; \quad P=0.004)$, on the other hand, honey production decreases in enterprises with more colony losses $(r=-0.311 ; P<0.001)$. There appears to be any research exploring about organic beekeeping in Turkey to compare this study.

Table 10. Product diversity status by professional priority order

\begin{tabular}{|c|c|c|c|c|c|}
\hline \multirow[b]{2}{*}{ Priority Order } & & \multicolumn{3}{|c|}{ Product Diversity } & \multirow{2}{*}{ Total } \\
\hline & & Unchanged & Increased & Decreased & \\
\hline \multirow{2}{*}{ First Priority } & $\mathrm{n}$ & 51 & 14 & 11 & 76 \\
\hline & $\%$ & $67.10 \%$ & $18.40 \%$ & $14.50 \%$ & $100.00 \%$ \\
\hline \multirow{2}{*}{ Second Priority } & $\mathrm{n}$ & 26 & 1 & 1 & 28 \\
\hline & $\%$ & $92.90 \%$ & $3.60 \%$ & $3.60 \%$ & $100.00 \%$ \\
\hline \multirow{2}{*}{ Third Priority } & $\mathrm{n}$ & 6 & 0 & 0 & 6 \\
\hline & $\%$ & $100.00 \%$ & $0.00 \%$ & $0.00 \%$ & $100.00 \%$ \\
\hline & $\mathrm{n}$ & & & & \\
\hline No response & & - & - & - & 8 \\
\hline
\end{tabular}

Table 11. Number of colonies by the method of obtaining the queen bee

\begin{tabular}{lccc}
\hline Queen Bee Obtaining Method & $\mathrm{n}$ & Mean & Standard Deviation \\
\hline Natural & 51 & 80.94 & 99.455 \\
Larval Grafting & 26 & 168.77 & 118.316 \\
Natural + Commercial Queen Bee & 17 & 117.06 & 75.789 \\
Commercial Queen Bee & 16 & 86.63 & 42.594 \\
Larval Grafting + Commercial Queen Bee & 3 & 289.33 & 218.177 \\
Natural + Larval Grafting & 3 & 182.67 & 99.806 \\
No response & 2 & - & - \\
\hline
\end{tabular}

$(P<0.001)$ 
Table 12. Relationship between colony number, colony loss, and honey production

\begin{tabular}{|c|c|c|c|c|}
\hline & & Colony Number & Colony Loss & Honey Production \\
\hline & $r$ & 1 & & \\
\hline \multirow[t]{3}{*}{ Colony Number } & $P$ & & & \\
\hline & $\mathrm{N}$ & 142 & & \\
\hline & r & -0.13 & 1 & \\
\hline \multirow[t]{3}{*}{ Colony Loss } & $P$ & 0.149 & & \\
\hline & $\mathrm{N}$ & 124 & 136 & \\
\hline & r & $.255^{* *}$ & $-.311^{* *}$ & 1 \\
\hline \multirow[t]{2}{*}{ Honey Production } & $P$ & 0.004 & 0 & \\
\hline & $\mathrm{N}$ & 124 & 128 & 138 \\
\hline
\end{tabular}

\section{Conclusion}

In Turkey, organic beekeeping activities are carried out under the "Organic Farming Law" numbered 5262 (Anonymous, 2004), and the "Regulation on Principles and Implementation of Organic Agriculture" came into force with the Official Gazette dated 18 August 2010 and numbered 27676 (Anonymous, 2010). Organic beekeeping is a production model made only with allowed inputs without using drugs that are harmful to human health and whose every stage is controlled and certified from production to consumption. In the regulation of organic beekeeping, conditions for performing many activities such as colony development, additional feeding, disease and pest control, location selection, characteristics of colonies and queen bees, use of honeycomb frame, and harvesting are clearly stated. In this study, it was observed that the use of syrup and cake (41\%) is performed intensely in the additional feeding activities of the enterprises. Concerning additional feeding, the regulation includes the following statement: "Organic honey is used in feeding bee colonies during the spring period. In cases where climatic conditions accelerate the crystallization of honey, the use of sugar syrup or organic sugar molasses, produced by organic methods may be allowed by the authorized organization, instead of honey produced by an organic method in feeding." It was determined that the enterprises had difficulty accessing organic sugar and derivative products when they needed them. It was determined that about $65 \%$ of the enterprises used the Caucasian or Caucasian hybrid queen bee race in their colonies, while $15 \%$ of them used the queen bee races of foreign origin. It is considered that in terms of preserving and ensuring the sustainability of our native honey bee races and genotypes, our local bees should be kept at the forefront of production activities.

The organic beekeeping enterprises reported that the biggest threat was the Varroa destructor parasite regarding the diseases and pests' issue. It was observed that a large proportion of the enterprises correctly planned the time of spraying against varroa. It was also determined that some enterprises resorted to chemical methods in fighting this parasite. It is recommended that organic acids, which do not leave residues in bee products, should be used more widely in fighting against parasites by enterprises and that the dose, method of use, and location differences of the effective control organic acids should be supported by scientific studies. In this study, it was determined that record-keeping operation, one of the most important factors affecting success in beekeeping, achieving at a high level by the organic beekeeping enterprises. Annual colony losses of enterprises were found to be greater in enterprises that obtained the queen bee commercially and bred the queen bee by natural means than in enterprises that transfer larvae. It was determined that enterprises that considered organic beekeeping as the first profession had a high number of colonies and fewer colony losses compared to enterprises that saw it in the second and third orders. It was also observed the production of organic bee products other than honey was carried out at a very limited level that in the enterprises. It is believed that the popularization of organic production of bee products with high nutrient content, such as royal jelly imported from abroad, pollen, propolis, bee bread, and apilarnil, will make a significant contribution to the Turkish economy.

\section{Acknowledgement}

This study includes a part of the project "Examination of the Socio-Economic Structure of Organic Beekeeping Enterprises in Turkey" numbered "TAGEM/TEAD/17/A08/P01/003" and supported by the General Directorate of Agricultural Research and Policies of the Ministry of Agriculture and Forestry. Researchers thank the institutions, organizations, and enterprises that contributed to the survey. 


\section{References}

Anonymous, (2004). Organik Tarım Kanunu, Official Gazette No.:25659 and dated 01.12.2004.

Anonymous, (2010). Organik Tarımın Esasları ve Uygulanmasına İlişkin Yönetmelik, Tarım ve Köyişleri Bakanlığı, Official Gazette No. 27676 and dated 18.08.2010.

Anonymous, (2021). Tarım ve Orman Bakanlığı, Organik Tarım Bilgi Sistemi. Retrieved from http://organik.tarim.gov.tr/veri/default.asp

Cengiz, M. M. (2013). Doğal Mera Alanlarının Arıcılık ve Organik Bal Üretimi Açısından Önemi. Arıcılık Araştırma Dergisi, 5(1), 14-16.

Emsen, B., \& Genç, F. (2004). Organik Bal Üretimi. 4. Ulusal Zootekni Bilim Kongresi (pp.110-112). Isparta, Turkey.

Gökçe, M. (2002). Organik Arıcılık. Tarım ve Köyişleri Bakanlığı, Organik Tarım Eğitim Sunumları, Ankara.

Gül, A., Şahinler, N., Akyol, E., \& Şahin, A. (2005). Organik Arı
Yetiștiriciliği. M.K.Ü. Ziraat Fakültesi Dergisi, 10(1-2), 63 70.

Korkmaz, A. (2001). Ülkemiz Ballarında Kalıntı Sorunu ve İnsan Sağlığı Açısından Önemi. Türkiye 2. Ekolojik Tarım Sempozyumu. Antalya, Turkey.

Özsayın, D., Tan, S., \& Everest, B. (2018). Gökçeada İlçesinde Organik Arıcılık Yapan İşletmelerin Sosyo-Ekonomik Yapısı ve Pazarlama Olanaklar. IX. IBANESS Congress Series (pp.236-245).

Saner, G., Yücel, B., Yercan, M., Karaturhan, B., Engindeniz, S., Çukur, F., \& Kösoğlu, M. (2011). Organik ve Konvansiyonel Bal Üretiminin Teknik ve Ekonomik Yönden Geliştirilmesi ve Alternatif Pazar Olanaklarının Saptanması Üzerine Bir Araştırma: İzmir ili Kemalpaşa İlçesi Örneği (Edition Number:195).Ankara, Turkey: T.C. Gıda Tarım ve Hayvancılık Bakanlığı, Tarımsal Ekonomi ve Politika Geliştirme Enstitüsü.

Yamane, T. (1967). Statistics, an Introductory Analysis, $2^{\text {nd }} E d$. New York: Harper and Row. 